\title{
Article \\ Phosphorus and Carbohydrate Metabolism in Green Bean Plants Subjected to Increasing Phosphorus Concentration in the Nutrient Solution
}

\author{
Pedro García-Caparrós ${ }^{1}$, María Teresa Lao ${ }^{1, *(D)}$, Pablo Preciado-Rangel ${ }^{2}$ and Esteban Sanchez ${ }^{3,4}$ \\ 1 Department of Superior School Engineering, University of Almeria, CIAIMBITAL, Agrifood Campus of \\ International Excellence ceiA3. Ctra. Sacramento s/n, La Cañada de San Urbano, 04120 Almería, Spain; \\ pedrogar123@hotmail.com \\ 2 National Technological Institute of México-Technological Institute of Torreón (ITT), 22710 Torreón, Coahuila, \\ Mexico; pablopreciado@gmail.com \\ 3 Center for Research in Food and Development A.C., 33086 Delicias, Chihuahua, Mexico; esteban@ciad.mx \\ 4 Faculty of Agrotechnological Sciences, University Autonomous of Chihuahua, 31000 Rosales, Chihuahua, \\ Mexico \\ * Correspondence: mtlao@ual.es; Tel.: +34-950-015876; Fax: +34-950-015939
}

Citation: García-Caparrós, P.; Lao, M.T.; Preciado-Rangel, P.; Sanchez, E. Phosphorus and Carbohydrate Metabolism in Green Bean Plants Subjected to Increasing Phosphorus Concentration in the Nutrient Solution. Agronomy 2021, 11, 245. https://doi.org/10.3390/ agronomy11020245

Academic Editor: Georgia Ntatsi Received: 13 December 2020

Accepted: 23 January 2021

Published: 28 January 2021

Publisher's Note: MDPI stays neutral with regard to jurisdictional claims in published maps and institutional affiliations.

Copyright: (c) 2021 by the authors. Licensee MDPI, Basel, Switzerland. This article is an open access article distributed under the terms and conditions of the Creative Commons Attribution (CC BY) license (https:// creativecommons.org/licenses/by/ $4.0 /)$.

\begin{abstract}
Phosphorus (P) is considered an elementary mineral nutrient for plants. Nevertheless, excessive or deficit supply to the crop may cause negative changes at the physiological level. Plants were cultivated in pots in a growth chamber under increasing $\mathrm{P}$ concentration $\left(\mathrm{P}_{1}(0.5 \mathrm{mmol} / \mathrm{L}\right.$ (control treatment)), $\mathrm{P}_{2}(1 \mathrm{mmol} / \mathrm{L}) ; \mathrm{P}_{3}(2 \mathrm{mmol} / \mathrm{L}) ; \mathrm{P}_{4}(4 \mathrm{mmol} / \mathrm{L}) ; \mathrm{P}_{5}(6 \mathrm{mmol} / \mathrm{L})$, and $\left.\mathrm{P}_{6}(8 \mathrm{mmol} / \mathrm{L})\right)$ in the nutrient solution for 40 days. At the end of the experimental period, biomass, carbohydrates concentration, and enzymatic activities related to the synthesis and degradation of sucrose as well as the different fractions of $\mathrm{P}$ in different organs of the plant were assessed. The results obtained in this experiment reveal a decrease in biomass under increasing P supply. Fructose, glucose, sucrose, and starch concentrations were higher in the shoots compared to the roots. There were different trends in the roots and shoots in enzymatic activities related to sucrose. The increase in P dose increased the concentration of the different forms assessed for P in all the organs studied. Seed phytate concentration surpassed the threshold established by the Food and Agriculture Organization (FAO) for green bean plants grown under $\mathrm{P}_{4}, \mathrm{P}_{5}$, and $\mathrm{P}_{6}$ treatments. Considering the results obtained, we suggest fertigation with a concentration of $2 \mathrm{mmol} / \mathrm{L}$ to obtain a higher productivity without excess of phytate in seeds.
\end{abstract}

Keywords: acid phosphatase activity; fructose 1,6-biphosphatase; invertases; lipidic-P; phytate; sucrose

\section{Introduction}

Green beans (Phaseolus vulgaris L.) are a legume with high relevance in human nutrition due to their high amounts of calories and proteins [1,2]. According to the Food and Agriculture Organization (FAO) [3], at the worldwide level, the area harvested and the production quantity of green beans were 1,569,474 ha and 2,4765,555 $t$, respectively.

Phosphate reserves for agriculture are running out, and at the agronomic level there are various aspects related to the soil and fertilization $[4,5]$.

Phosphorus is a relevant macronutrient in a plant's growth, ranging from 0.05 to $0.30 \%$ of the crop's dry weight [6]. Phosphorus (P) participates in many physiological processes associated with plant growth and development. For instance, $\mathrm{P}$ is crucial in energy metabolism and photosynthesis, biosynthesis of organic compounds, the structural element of nucleic acids and phospholipids, up and down regulation of genes and the activity of enzymes, and also in signal transduction $[7,8]$. 
In the soil, there are several chemical forms of $\mathrm{P}$, such as inorganic $\mathrm{P}(\mathrm{Pi})$ and organic $\mathrm{P}(\mathrm{Po})[9,10]$. The concentration of Pi in plant tissues ranges from 5 to $20 \mathrm{mM}$ [11], being higher than the concentration in the soil, which is around $10 \mathrm{mM}$ [12]. Plants uptake phosphorus from the soil as inorganic phosphate (Pi) in the forms of $\mathrm{HPO}_{4}{ }^{2-}$ or $\mathrm{H}_{2} \mathrm{PO}_{4}{ }^{-}$ ions $[13,14]$. Moreover, an adequate rate of $\mathrm{P}$ uptake is of crucial interest for plant's growth and development, since a reduced availability results in a decline in crop yield [15].

Plant growth requires the translocation of carbohydrates from the leaves to the rest of the plant, providing these organs with carbon and energy. Among these carbohydrates, sucrose is the most important in plants [16]. The synthesis of sucrose occurs in the cytoplasm from triose-P that is translocated from the chloroplast in a Pi-regenerating step. The triose-P ubicated in the cytosol is firstly transformed to hexose-P to be later converted into sucrose [17].

The key enzymes participating in the generation of sucrose are fructose-1,6- biphosphatase (F1,6BPase), uridine di-phosphate UDP-glucose pyrophosphorylase, and sucrosephosphate synthase (SPS) [18]. The sucrose degradation rates depend on sucrose synthase (SS), as well as on acidic and alkaline sucrose invertase activities, yielding in both cases glucose and fructose $[19,20]$. Sucrose phosphate synthase is soluble in the cytoplasm and participates in the reversible formation of sucrose-P from UDP-glucose. Fru-6-P' activity of this enzyme is led mainly by allosteric effectors (Glc-6-P and $\mathrm{Pi}$ ) and by reversible seryl phosphorylation [21]. Soluble sucrose invertases participate in the hydrolytic reaction of sucrose, producing glucose and fructose, and according to the optimum $\mathrm{pH}$ and cell compartmentation studies, they are ubicated in the cytoplasm (neutral or alkaline forms) or in the vacuole (acid forms) [22].

The level of $\mathrm{P}$ in a crop can be assessed as different $\mathrm{P}$ pools depending on the extraction procedure. The different $\mathrm{P}$ forms are related to different chemical compounds such as ester, lipid, nucleotide, inorganic and storage P [12]. Inorganic P is ubicated either in the vacuole, where it is translocated to satisfy the requirements of growing sinks, or in the cytosol acting as a crucial regulator of the leaf $\mathrm{CO}_{2}$ assimilation rate [23]. By contrast, the organic fraction of phosphorus (Po) needs to be hydrolyzed to Pi before it can be re-translocated [24]. The fractions of $\mathrm{Pi}$ and Po must be converted to the soluble form of $\mathrm{P}$ to easily be used up as a P nutrient by plants, and thereafter be immobilized into organic cellular macromolecules such as DNA, RNA and ATP [25]. The activation of intracellular and secreted acid phosphatases (APase) is a well-known response against $\mathrm{P}$ deprivation in plants [8].

Reviewing the literature, there are several studies focused on the effects of phosphate limitation in common beans at the biochemical and physiological level [26-29]. Nevertheless, these studies were conducted under a phosphate-sufficient $(+\mathrm{P})$ and phosphate deficient $(-\mathrm{P})$ nutrient medium, with no comparison between the supply of different doses of $\mathrm{P}$. Therefore, this experiment aimed to discern the effects of different doses of $\mathrm{P}$ on the biomass, metabolism, and distribution of carbohydrates and phosphorus in green bean plants.

\section{Materials and Methods}

\subsection{Plant Material and Growth Conditions}

Green bean seeds cv. Strike were germinated for 8 days under dark conditions and then transplanted to $8 \mathrm{~L}^{-1}$ pots (4 plants) filled with vermiculite. Plants were cultivated in a growth chamber with $350 \mu \mathrm{mol} \mathrm{m}{ }^{-2} \mathrm{~s}^{-1}$ (photon flux density) (recorded at the canopy of the crop with a quantum sensor (LI-190SA, LI-COR Inc., Lincoln, NE, USA), a photoperiod of $16 / 8 \mathrm{~h}$ (day/night), an average day /night temperature of $28 / 22^{\circ} \mathrm{C}$, and air humidity ranging from 60 to $80 \%$. These plants were irrigated for 20 days before the experimental treatments with a complete nutrient solution containing $6 \mathrm{mmol} / \mathrm{L}\left(\mathrm{NH}_{4} \mathrm{NO}_{3}\right), 2.4 \mathrm{mmol} / \mathrm{L}$ $\left(\mathrm{K}_{2} \mathrm{SO}_{4}\right), 1.2 \mathrm{mmol} / \mathrm{L}\left(\mathrm{CaCl}_{2} \cdot 2 \mathrm{H}_{2} \mathrm{O}\right), 1.6 \mathrm{mmol} / \mathrm{L}\left(\mathrm{K}_{2} \mathrm{HPO}_{4}\right), 1.4 \mathrm{mmol} / \mathrm{L}\left(\mathrm{MgSO}_{4} \cdot 7 \mathrm{H}_{2} \mathrm{O}\right)$, $5 \mu \mathrm{mol} / \mathrm{L}(\mathrm{Fe}-\mathrm{EDDHA}), 1 \mu \mathrm{mol} / \mathrm{L}\left(\mathrm{ZnSO}_{4} \cdot 7 \mathrm{H}_{2} \mathrm{O}\right), 2 \mu \mathrm{mol} / \mathrm{L}\left(\mathrm{MnSO}_{4} \cdot \mathrm{H}_{2} \mathrm{O}\right), 0.3 \mu \mathrm{mol} / \mathrm{L}$ $\left[\left(\mathrm{NH}_{4}\right)_{6} \mathrm{Mo}_{7} \mathrm{O}_{24} \cdot 4 \mathrm{H}_{2} \mathrm{O}\right], 0.25 \mu \mathrm{mol} / \mathrm{L}\left(\mathrm{CuSO}_{4} \cdot 5 \mathrm{H}_{2} \mathrm{O}\right)$ and $5 \mu \mathrm{mol} / \mathrm{L}\left(\mathrm{H}_{3} \mathrm{BO}_{3}\right)$. The com- 
pleted nutrient solution was renewed two times per week during the whole experimental period, with a $\mathrm{pH}$ of 6.0-6.1. Twenty days after the sowing, different $\mathrm{P}$ concentrations were added to the nutrient solution to establish the different $\mathrm{P}$ treatments. The desired concentrations of $\mathrm{P}$ were obtained using the following chemical fertilizers: monopotassium phosphate $\left(\mathrm{KH}_{2} \mathrm{PO} 4\right)$ and phosphoric acid $\left(\mathrm{H}_{3} \mathrm{PO}_{4}\right)$. The treatments of $\mathrm{P}$ were: $\mathrm{P}_{1}$ (0.5 mmol/L (control treatment)), $\mathrm{P}_{2}(1 \mathrm{mmol} / \mathrm{L}) ; \mathrm{P}_{3}(2 \mathrm{mmol} / \mathrm{L}) ; \mathrm{P}_{4}(4 \mathrm{mmol} / \mathrm{L}) ; \mathrm{P}_{5}$ $(6 \mathrm{mmol} / \mathrm{L})$, and $\mathrm{P}_{6}(8 \mathrm{mmol} / \mathrm{L})$, and these were applied for 40 days (until harvest). The experiment consisted of a randomized complete block design with six single-pot replications with a total of 24 plants per treatment. At the end of the experiment (60 days after sowing), plants at full maturity were sampled and sorted into roots, shoots, pods, and seeds for further analysis. The different samples were cleaned three times with distilled water and nonionic detergent (1\%) [30] and then were blotted on filter paper.

Fresh root and shoot subsamples were used to determine the activities of fructose1,6-bisphosphatase (F1,6BPase), sucrose phosphate synthase (SPS), sucrose synthase (SS), invertases (acid and alkaline), and the concentration of non-structural carbohydrates (sucrose, glucose, fructose and starch). Acid phosphatase activity was also assessed in subsamples of the fresh weight of roots, shoots, pods, and seeds. Oven-dried $\left(70{ }^{\circ} \mathrm{C}\right.$ until constant weight) subsamples of the different organs assessed were ground in a mill, and then used for the analysis of total $\mathrm{P}$, inorganic $\mathrm{P}$, organic soluble- $\mathrm{P}$, lipidic- $\mathrm{P}$, proteic- $\mathrm{P}$, RNA-P, DNA-P, and phytates.

\subsection{Analysis of Carbohydrates Metabolism}

Fresh material of roots and shoots was crushed with ethanol $(5 \mathrm{~mL}$ at $96 \%)$ and then washed with ethanol ( $5 \mathrm{~mL}$ at $70 \%)$. The alcoholic extract was centrifuged for $10 \mathrm{~min}$ $(3500 \times g)$ and then the supernatant was stored at $4{ }^{\circ} \mathrm{C}$ for further analysis. The determination of the concentration of soluble sugars, such as sucrose, glucose, and fructose, was assessed with the protocol established by Irigoyen et al. [31]. The pellet obtained after centrifugation was dried and then incubated for $48 \mathrm{~h}$ at $37{ }^{\circ} \mathrm{C}$ in buffer acetate $(4.5 \mathrm{mM})$ and $\alpha$-glucoamylase $(0.5 \%, w / v)$ and water for the determination of starch. The reagent of anthrone was used for the determination of the concentration of soluble sugars and starch measuring the absorbance at $650 \mathrm{~nm}$ and using standards of sucrose, glucose, and fructose at different concentrations. The concentration of soluble sugars (sucrose, glucose, fructose) and starch in roots and shoots was expressed as $\mathrm{mg} \mathrm{g}^{-1} \mathrm{FW}$.

Sucrose phosphate synthase (SPS) activity was assessed with the methodology reported by Hubbard et al. [32]. The extraction medium containing: Hepes-NaOH buffer (1:5 $(w / v), 0,05 \mathrm{M}, \mathrm{pH} 7.5)$ with $1 \mathrm{mM}$ Na-EDTA, $5 \mathrm{mM} \mathrm{MgCl}_{2}, 0.5 \mathrm{BSA} \mathrm{g} \mathrm{L}^{-1}, 2.5 \mathrm{mM}$ DTT, and $0.05 \%(v / v)$ Triton X-100. The homogenate was centrifuged for $10 \mathrm{~min}(13,500 \times g)$ and the enzyme activity was assessed in the resulting extract. The protocol of Bradford [33] was conducted to determine protein concentration. SPS activity was determined in reaction mixtures containing $50 \mathrm{mM}$ Hepes- $\mathrm{NaOH}$ (pH 7.5), $15 \mathrm{mM} \mathrm{MgCl}$, $25 \mathrm{mM}$ glucose 6-phosphate, $25 \mathrm{mM}$ fructose 6-phosphate, $25 \mathrm{mM}$ UDP-glucose, and $100 \mu \mathrm{L}$ of extract, using the protocol reported by Cheikh and Brenner [34]. The incubation of the mixtures $\left(37^{\circ} \mathrm{C}\right.$ ) was conducted for $30 \mathrm{~min}$ and was stopped with the addition of $70 \mu \mathrm{L}$ of potassium hydroxide $(30 \%, w / v)$. Enzyme blanks were finished with potassium hydroxide at 0 min. Sucrose was determined using Van Handel's [35] modified anthrone method. The activity of SPS was expressed as $\mu \mathrm{mol}$ sucrose $\mathrm{mg}^{-1}$ prot. $\mathrm{h}^{-1}$. Sucrose synthase (SS) was determined using the same methodology proposed for SPS, but using fructose (25 $\mathrm{mM})$ instead of fructose 6-phosphate, and without glucose 6-phosphate [34]. The activity of SS was expressed as $\mu \mathrm{mol}$ sucrose $\mathrm{mg}^{-1}$ prot. $\mathrm{h}^{-1}$.

Fructose 1,6-biphosphatase (F1,6BPase) was extracted following the protocol of Holaday et al. [36]. The activity of the enzyme was assessed in a reaction mixture composed of $50 \mathrm{mM}$ Hepes- $\mathrm{HCl}$ (pH 7.6), $5 \mathrm{mM} \mathrm{MgCl}_{2}, 10 \mathrm{mM} \beta$-mercaptoethanol, $0.25 \mathrm{mM}$ fructose 1,6biphosphate, $10 \mathrm{mM} \mathrm{KF}$, and $100 \mu \mathrm{L}$ of extract. Then, the reaction mixture was incubated in dark conditions for $10 \mathrm{~min}$ at $25^{\circ} \mathrm{C}$ and stopped with the addition of trichloroacetic acid 
(30\%). The protocol of Bradford [33] was conducted to determine protein concentration. The Pi released was measured with the protocol of Geladopoulus et al. [37]. Fructose 1,6-biphosphatase activity was expressed as $\mu \mathrm{mol} \mathrm{Pi}^{-1} \mathrm{mg}^{-1}$ prot. $\mathrm{min}^{-1}$.

Invertases (acid and alkaline) were extracted in potassium phosphate buffer $(0.2 \mathrm{M}$, pH 7.0) and $\beta$-mercaptoethanol (0.02 M) using the protocol reported by Hubbard et al. [32]. The homogenate obtained was filtered and centrifuged for $15 \mathrm{~min}(35,000 \times g)$. The resulting extract was used to determine enzyme activities and soluble protein concentration. The enzymatic activity for acid invertase was assessed using $55 \mu \mathrm{L}$ of extract, $150 \mu \mathrm{L}$ sodium acetate buffer $(0.1 \mathrm{M}, \mathrm{pH} 4.5)$, and $50 \mu \mathrm{L}$ sucrose $(0.75 \mathrm{M})$ in a test tube equilibrated in a $37{ }^{\circ} \mathrm{C}$ water bath. The reaction lasted $30 \mathrm{~min}$ and was stopped by adding a volume of $125 \mu \mathrm{L}$ dinitrosalicylic acid reagent prepared according to Miller's method [38]. The protocol of Bradford [33] was conducted to determine protein concentration. Reducing sugars released from sucrose were measured with the protocol of Hubbard et al. [32]. The activity of neutral invertase was assessed as described above but sodium-acetate buffer (0.1 M, pH 4.5) was replaced with $\mathrm{K}_{2} \mathrm{HPO}_{4}{ }^{-}$citrate buffer $(0.1 \mathrm{M}, \mathrm{pH} 7.0)$ [32]. Invertase (acid and alkaline) activities were expressed as $\mu \mathrm{mol}$ glucose $\mathrm{mg}^{-1}$ prot. $\mathrm{h}^{-1}$.

\subsection{Analysis of P Forms}

Dry matter subsamples were ground and then digested with sulfuric acid (96\%) and hydrogen peroxide $\left(\mathrm{H}_{2} \mathrm{O}_{2}\right)$ [30]. Total $\mathrm{P}$ was analyzed by the vanadomolybdophosphate colorimetric method measuring the absorbance at $430 \mathrm{~nm}[39,40]$. An aqueous extraction ( $0.2 \mathrm{~g}$ of dried material in a volume of $10 \mathrm{~mL}$ of distilled water) was filtrated, and the eluate was used for the direct determination of the inorganic $\mathrm{P}$, as was described previously for total form [40]. The concentration of organic $P$ resulted from the difference between total and inorganic P. Lipidic P was extracted using ethanol-ether-chloroform $(2-2-1 / v)$ from the first extraction residue at $50{ }^{\circ} \mathrm{C}$ for $60 \mathrm{~min}$ and then centrifuged at $3000 \times g$ for $5 \mathrm{~min}$. An aliquot of this supernatant was desiccated and then digested with $96 \% \mathrm{H}_{2} \mathrm{SO}_{4}$ for the colorimetric determination at $430 \mathrm{~nm}[39,40]$. RNA-P was determined using an aliquot of the extraction residue of lipidic P determination, which was desiccated and then used for the extraction with $\mathrm{KOH}$ and centrifuged for $5 \mathrm{~min}(3000 \times \mathrm{g})$. An aliquot of the supernatant obtained was desiccated and then digested with $96 \% \mathrm{H}_{2} \mathrm{SO}_{4}$ for the colorimetric determination at $430 \mathrm{~nm}[39,40]$. DNA-P was determined using an aliquot of the extraction residue of RNA-P which was desiccated and then used for the extraction with $5 \% \mathrm{HClO}_{4}$ and centrifuged for $5 \mathrm{~min}(3000 \times g)$. An aliquot of the supernatant obtained was desiccated and then digested with $96 \% \mathrm{H}_{2} \mathrm{SO}_{4}$ for the colorimetric determination at $430 \mathrm{~nm}[39,40]$. Proteic $\mathrm{P}$ was determined using an aliquot of the extraction residue of DNA-P which was desiccated and then digested with $96 \% \mathrm{H}_{2} \mathrm{SO}_{4}$ for the colorimetric determination at $430 \mathrm{~nm}[39,40]$. The different $\mathrm{P}$ forms calculated were expressed in $\mathrm{mg}$ $100 \mathrm{~g}^{-1} \mathrm{DW}$.

Acid phosphatase activity (APA) assay was measured following the protocol of Besford [41], Ruiz et al. [42], and López-Cantarero et al. [40]. The fresh weight of the different sections assessed was homogenized with a $0.1 \mathrm{M}$ Na-acetate buffer, and then centrifuged at $30,000 \times g$ being always at $4{ }^{\circ} \mathrm{C}$. The protocol of Bradford [33] was conducted to determine protein concentration. Enzyme extracts were incubated under dark conditions (30 min) at $30{ }^{\circ} \mathrm{C}$. Hydrolysis of the p-nitrophenyl phosphate ( $\mathrm{p}$-NPP) was recorded as APA measuring the absorbance at $405 \mathrm{~nm}$. The activity of APA was expressed as $\mu \mathrm{mol}$ of p-NPP hydrolyzed $\mathrm{h}^{-1}$ at $30^{\circ} \mathrm{C}$.

Phytate concentration was determined in dried and ground seeds which were treated with $\mathrm{HCl}$. This determination was based on phytate extraction in a strongly acidic media, and the subsequent phytate-Fe complex arrangement by means of high Fe present in the reaction media as ammonium iron sulphate. From the supernatant fraction, the phytate concentration was determined by 2,2 '-bipyridine following the procedure established by

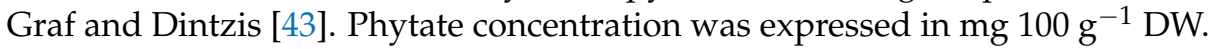




\subsection{Statistical Analysis}

Statistical analyses of the variables studied were conducted using the program Statgraphics Centurion XVI.II (Statpoint Technologies, Inc., Warrenton, VA, USA). The significance of the effects of the treatments was analyzed by ANOVA (one-way analysis of variance) and LSD (least significant difference) tests $(p<0.05)$.

\section{Results}

\subsection{Plant Parameters}

Green bean plants grown under $\mathrm{P}_{1}$ showed the highest value in roots, whereas plants grown under $\mathrm{P}_{3}$ and $\mathrm{P}_{4}$ showed the highest value in shoot and pod dry weight at the end of the experiment (Figure 1).

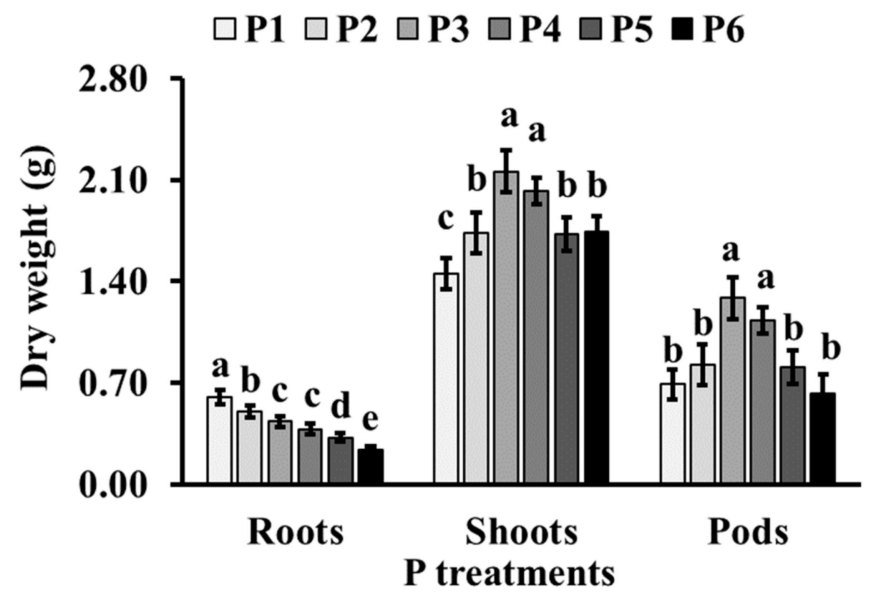

Figure 1. Effects of different $P$ treatments on root, shoot, and pod dry weight in green bean plants at the end of the experiment. Means with the same lower-case letter are not significantly different at $p<0.05$ according to LSD and one-way ANOVA. Error bars represent standard deviation of the means (SE), $n=6$.

\subsection{Carbohydrates Metabolism}

Green bean plants showed higher concentrations of glucose, fructose, sucrose, and starch in shoots compared to roots at the end of the experiment. At root level, plants grown under $\mathrm{P}_{3}$ and $\mathrm{P}_{4}$ showed the highest concentration of glucose, fructose, and sucrose. In shoots, plants grown under the lowest $\left(\mathrm{P}_{1}\right)$ phosphorus concentration supplied to the nutrient solution showed the highest concentration of glucose, fructose, and sucrose. With respect to starch, there were no significant differences between treatments at root and shoot level (Table 1).

With respect to sucrose biosynthesis, the values of sucrose phosphate synthase (SPS) and fructose 1,6-biphosphatase (F1,6BPase) were higher in plants grown under $\mathrm{P}_{3}$ and $\mathrm{P}_{4}$ at root and shoot level at the end of the experiment. The enzymes involved in sucrose degradation, sucrose synthase, and acid and alkaline invertase activities in roots were higher in plants grown under $\mathrm{P}_{3}$ and $\mathrm{P}_{4}$, whereas in shoots, sucrose synthase activity was higher under $\mathrm{P}_{3}$ and $\mathrm{P}_{4}$, while acid and alkaline invertase activities showed the lowest value under these $P$ treatments (Table 2). 
Table 1. Effects of different $P$ treatments on the accumulation of non-structural carbohydrates in the roots and shoots of green bean plants at the end of the experiment. $n=6$. Means \pm standard deviation within columns with different lower-case letters are significantly different at $p<0.05$ (one-way ANOVA and LSD tests).

\begin{tabular}{ccccc}
\hline Treatments & $\begin{array}{c}\text { Glucose } \\
\left(\mathbf{m g ~ g}^{-\mathbf{1}} \mathbf{F W}\right)\end{array}$ & $\begin{array}{c}\text { Fructose } \\
\left(\mathbf{m g ~ g}^{-\mathbf{1}} \mathbf{F W}\right)\end{array}$ & $\begin{array}{c}\text { Sucrose } \\
\left(\mathbf{m g ~ g}^{-\mathbf{1}} \mathbf{F W}\right)\end{array}$ & $\begin{array}{c}\text { Starch } \\
\left.\mathbf{( m g ~}^{-\mathbf{1}} \mathbf{F W}\right)\end{array}$ \\
\hline Roots & & & \\
\hline $\mathrm{P}_{1}$ & $2.05 \pm 0.18 \mathrm{~d}$ & $2.19 \pm 0.19 \mathrm{~d}$ & $1.99 \pm 0.17 \mathrm{~d}$ & $11.75 \pm 1.02 \mathrm{a}$ \\
$\mathrm{P}_{2}$ & $2.68 \pm 0.23 \mathrm{c}$ & $2.85 \pm 0.25 \mathrm{c}$ & $2.59 \pm 0.23 \mathrm{c}$ & $11.69 \pm 1.02 \mathrm{a}$ \\
$\mathrm{P}_{3}$ & $6.44 \pm 0.56 \mathrm{a}$ & $6.86 \pm 0.60 \mathrm{a}$ & $6.23 \pm 0.54 \mathrm{a}$ & $11.11 \pm 0.97 \mathrm{a}$ \\
$\mathrm{P}_{4}$ & $6.68 \pm 0.58 \mathrm{a}$ & $7.11 \pm 0.62 \mathrm{a}$ & $6.46 \pm 0.56 \mathrm{a}$ & $12.14 \pm 1.06 \mathrm{a}$ \\
$\mathrm{P}_{5}$ & $4.52 \pm 0.39 \mathrm{~b}$ & $4.81 \pm 0.42 \mathrm{~b}$ & $4.37 \pm 0.38 \mathrm{~b}$ & $11.58 \pm 1.27 \mathrm{a}$ \\
$\mathrm{P}_{6}$ & $2.60 \pm 0.23 \mathrm{c}$ & $2.77 \pm 0.24 \mathrm{c}$ & $2.52 \pm 0.22 \mathrm{c}$ & $10.28 \pm 0.90 \mathrm{a}$ \\
\hline Shoots & & & & \\
\hline $\mathrm{P}_{1}$ & $17.13 \pm 1.49 \mathrm{a}$ & $18.25 \pm 1.59 \mathrm{a}$ & $16.57 \pm 1.44 \mathrm{a}$ & $13.96 \pm 1.65 \mathrm{a}$ \\
$\mathrm{P}_{2}$ & $11.16 \pm 0.97 \mathrm{~b}$ & $11.89 \pm 1.04 \mathrm{~b}$ & $10.80 \pm 0.94 \mathrm{~b}$ & $13.01 \pm 1.40 \mathrm{a}$ \\
$\mathrm{P}_{3}$ & $10.37 \pm 0.90 \mathrm{~b}$ & $11.04 \pm 0.96 \mathrm{~b}$ & $10.03 \pm 0.87 \mathrm{~b}$ & $14.02 \pm 1.36 \mathrm{a}$ \\
$\mathrm{P}_{4}$ & $10.14 \pm 0.88 \mathrm{~b}$ & $10.78 \pm 0.88 \mathrm{~b}$ & $10.05 \pm 0.88 \mathrm{~b}$ & $13.85 \pm 1.29 \mathrm{a}$ \\
$\mathrm{P}_{5}$ & $10.71 \pm 1.11 \mathrm{~b}$ & $10.54 \pm 1.18 \mathrm{~b}$ & $9.81 \pm 0.86 \mathrm{~b}$ & $13.35 \pm 1.16 \mathrm{a}$ \\
$\mathrm{P}_{6}$ & $10.59 \pm 1.05 \mathrm{~b}$ & $11.68 \pm 1.02 \mathrm{~b}$ & $10.29 \pm 1.07 \mathrm{~b}$ & $14.13 \pm 1.23 \mathrm{a}$ \\
\hline
\end{tabular}

Table 2. Effects of different $P$ treatments on the key enzymes involved in the biosynthesis and degradation of sucrose in roots and shoots of green bean plants at the end of the experiment. $n=6$. Means \pm standard deviation within columns with different lower-case letters are significantly different at $p<0.05$ (one-way ANOVA and LSD tests).

\begin{tabular}{|c|c|c|c|c|c|}
\hline \multirow[b]{2}{*}{ Treatments } & \multicolumn{2}{|c|}{ Sucrose Biosynthesis } & \multicolumn{3}{|c|}{ Sucrose Degradation } \\
\hline & $\begin{array}{c}\text { SPS } \\
(\mu \mathrm{mol} \text { Sucrose } \\
\left.\mathrm{mg}^{-1} \text { prot. } \mathrm{h}^{-1}\right)\end{array}$ & $\begin{array}{c}\text { F1,6BPase } \\
(\mu \mathrm{mol} \mathrm{Pi} \\
\left.\mathrm{mg}^{-1} \text { prot. } \mathrm{min}^{-1}\right)\end{array}$ & $\begin{array}{c}\text { SS } \\
(\mu \mathrm{mol} \text { Sucrose } \\
\left.\mathrm{mg}^{-1} \text { prot. } \mathrm{h}^{-1}\right)\end{array}$ & $\begin{array}{l}\text { Acid Invertase } \\
(\mu \mathrm{mol} \text { Glucose } \\
\left.\mathrm{mg}^{-1} \text { prot. } \mathrm{h}^{-1}\right)\end{array}$ & $\begin{array}{c}\text { Alkaline } \\
\text { Invertase } \\
(\mu \mathrm{mol} \text { Glucose } \\
\left.\text { mg }^{-1} \text { prot. } \mathrm{h}^{-1}\right)\end{array}$ \\
\hline \multicolumn{6}{|l|}{ Roots } \\
\hline $\mathrm{P}_{1}$ & $5.02 \pm 0.44 c$ & $77.16 \pm 6.73 \mathrm{~d}$ & $3.62 \pm 0.32 c$ & $216.30 \pm 18.86 b$ & $229.00 \pm 19.96 \mathrm{~d}$ \\
\hline $\mathrm{P}_{2}$ & $5.17 \pm 0.45 c$ & $86.64 \pm 7.55 \mathrm{~d}$ & $3.39 \pm 0.30 c$ & $222.90 \pm 19.92 b$ & $234.80 \pm 20.47 \mathrm{~d}$ \\
\hline $\mathrm{P}_{3}$ & $8.79 \pm 0.77 a$ & $226.10 \pm 19.71 \mathrm{a}$ & $6.14 \pm 0.54 \mathrm{a}$ & $272.60 \pm 23.76 a$ & $411.10 \pm 35.84 \mathrm{a}$ \\
\hline $\mathrm{P}_{4}$ & $6.04 \pm 0.53 b$ & $165.80 \pm 14.45 \mathrm{~b}$ & $4.29 \pm 0.37 b$ & $300.61 \pm 26.21 \mathrm{a}$ & $452.90 \pm 39.48 a$ \\
\hline $\mathrm{P}_{5}$ & $3.73 \pm 0.40 \mathrm{~d}$ & $121.10 \pm 10.56 c$ & $2.87 \pm 0.24 c$ & $238.82 \pm 20.82 b$ & $342.20 \pm 29.83 b$ \\
\hline $\mathrm{P}_{6}$ & $4.17 \pm 0.36 \mathrm{~d}$ & $70.18 \pm 6.12 \mathrm{~d}$ & $2.97 \pm 0.26 \mathrm{c}$ & $166.81 \pm 14.54 \mathrm{c}$ & $272.82 \pm 23.78 \mathrm{c}$ \\
\hline \multicolumn{6}{|l|}{ Shoots } \\
\hline $\mathrm{P}_{1}$ & $4.27 \pm 0.37 c$ & $84.03 \pm 7.33 \mathrm{~d}$ & $3.51 \pm 0.31 c$ & $46.87 \pm 4.09 \mathrm{~b}$ & $155.10 \pm 13.52 \mathrm{a}$ \\
\hline $\mathrm{P}_{2}$ & $4.56 \pm 0.40 c$ & $108.80 \pm 10.36 c$ & $3.22 \pm 0.28 c$ & $21.63 \pm 1.89 c$ & $96.18 \pm 8.38 b$ \\
\hline $\mathrm{P}_{3}$ & $7.47 \pm 0.65 \mathrm{a}$ & $179.70 \pm 15.67 \mathrm{a}$ & $5.76 \pm 0.50 \mathrm{a}$ & $14.39 \pm 1.25 \mathrm{e}$ & $37.54 \pm 3.27 \mathrm{e}$ \\
\hline $\mathrm{P}_{4}$ & $6.60 \pm 0.40 b$ & $127.60 \pm 11.12 b$ & $4.43 \pm 0.39 \mathrm{~b}$ & $17.65 \pm 1.54 \mathrm{~d}$ & $59.10 \pm 5.15 d$ \\
\hline $\mathrm{P}_{5}$ & $4.17 \pm 0.36 \mathrm{c}$ & $107.90 \pm 9.41 \mathrm{c}$ & $3.70 \pm 0.32 c$ & $55.34 \pm 4.82 \mathrm{a}$ & $77.40 \pm 6.88 c$ \\
\hline $\mathrm{P}_{6}$ & $4.42 \pm 0.30 \mathrm{c}$ & $105.01 \pm 9.15 c$ & $3.31 \pm 0.29 c$ & $59.72 \pm 5.21 \mathrm{a}$ & $\pm 7.12 \mathrm{c}$ \\
\hline
\end{tabular}

\subsection{Phosphorus Metabolism}

There was a highly positive relationship $\left(\mathrm{R}^{2}=0.99\right)$ between the phosphorous concentration supplied to the nutrient solution and total $\mathrm{P}$ in the plant (Figure 2).

The concentrations of total and inorganic P forms increased under increasing phosphorus supply to the nutrient solution in all the organs studied (roots, shoots, pods, and seeds), showing the highest values in green bean plants subjected to the $\mathrm{P}_{6}$ treatment. Analogously, organic P concentration rose under increasing phosphorus supply to the nutrient solution in all the organs studied, showing the highest values in green bean plants subjected to $\mathrm{P}_{5}$ and $\mathrm{P}_{6}$ treatments, respectively, but with no significant differences between them. The 
ratio between organic and inorganic $\mathrm{P}$ increased under increasing phosphorus supply to the nutrient solution in roots, shoots, and pods, but in seeds it showed a contrary trend, showing the highest value in plants grown under $\mathrm{P}_{1}$ treatment (Table 3).

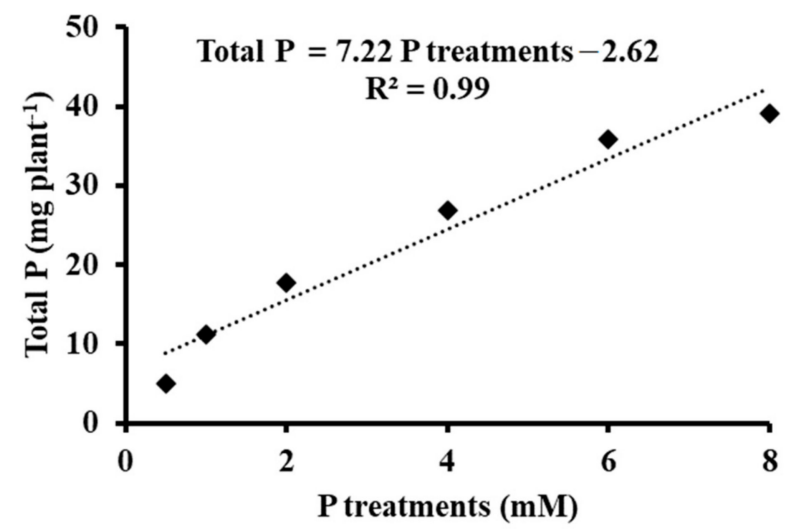

Figure 2. Relationship between $\mathrm{P}$ treatments (expressed in $\mathrm{mM}$ ) and total $\mathrm{P}$ (expressed in $\mathrm{mg} \mathrm{plant}^{-1}$ ).

Table 3. Effects of different $\mathrm{P}$ treatments on total, inorganic, organic and the organic $\mathrm{P} /$ inorganic $\mathrm{P}$ ratio in roots, shoots, pods, and seeds of green bean plants at the end of the experiment. $n=6$. Means \pm standard deviation within columns with different lower-case letters are significantly different at $p<0.05$ (One-way ANOVA and LSD tests).

\begin{tabular}{|c|c|c|c|c|}
\hline Treatments & $\begin{array}{c}\text { Total P } \\
\left(\mathrm{mg} 100 \mathrm{~g}^{-1} \mathrm{DW}\right)\end{array}$ & $\begin{array}{c}\text { Inorganic } P \\
\left(\mathrm{mg} 100 \mathrm{~g}^{-1} \mathrm{DW}\right)\end{array}$ & $\begin{array}{c}\text { Organic } P \\
\left(\mathrm{mg} 100 \mathrm{~g}^{1} \mathrm{DW}\right)\end{array}$ & $\begin{array}{c}\text { Organic } \\
\text { P/Inorganic } \mathbf{P}\end{array}$ \\
\hline \multicolumn{5}{|l|}{ Roots } \\
\hline $\mathrm{P}_{1}$ & $247.64 \pm 22.18 \mathrm{f}$ & $86.67 \pm 8.17 \mathrm{f}$ & $164.38 \pm 16.21 \mathrm{~d}$ & $0.53 \pm 0.04 \mathrm{e}$ \\
\hline $\mathrm{P}_{2}$ & $531.85 \pm 50.23 \mathrm{e}$ & $228.61 \pm 21.43 \mathrm{e}$ & $303.59 \pm 30.32 c$ & $0.75 \pm 0.06 \mathrm{~d}$ \\
\hline $\mathrm{P}_{3}$ & $686.31 \pm 64.25 \mathrm{~d}$ & $329.42 \pm 29.64 \mathrm{~d}$ & $357.98 \pm 33.60 c$ & $0.92 \pm 0.08 c$ \\
\hline $\mathrm{P}_{4}$ & $953.82 \pm 90.47 c$ & $476.90 \pm 44.58 c$ & $477.76 \pm 39.52 b$ & $1.00 \pm 0.09 c$ \\
\hline $\mathrm{P}_{5}$ & $1407.91 \pm 141.22 b$ & $814.58 \pm 79.28 b$ & $593.19 \pm 45.44 \mathrm{a}$ & $1.35 \pm 0.06 \mathrm{~b}$ \\
\hline $\mathrm{P}_{6}$ & $1655.56 \pm 153.28 \mathrm{a}$ & $991.82 \pm 80.22 \mathrm{a}$ & $664.58 \pm 65.27 \mathrm{a}$ & $1.49 \pm 0.07 \mathrm{a}$ \\
\hline \multicolumn{5}{|l|}{ Shoots } \\
\hline $\mathrm{P}_{1}$ & $167.08 \pm 14.49 \mathrm{f}$ & $50.12 \pm 4.72 \mathrm{f}$ & $117.11 \pm 13.59 \mathrm{~d}$ & $0.43 \pm 0.04 \mathrm{~d}$ \\
\hline $\mathrm{P}_{2}$ & $354.12 \pm 29.91 \mathrm{e}$ & $141.64 \pm 11.94 \mathrm{e}$ & $213.06 \pm 21.74 c$ & $0.66 \pm 0.06 c$ \\
\hline $\mathrm{P}_{3}$ & $449.02 \pm 38.90 \mathrm{~d}$ & $188.59 \pm 16.87 \mathrm{~d}$ & $261.76 \pm 25.96 c$ & $0.72 \pm 0.06 c$ \\
\hline $\mathrm{P}_{4}$ & $815.52 \pm 79.88 c$ & $375.14 \pm 31.46 c$ & $440.10 \pm 34.79 b$ & $0.85 \pm 0.08 b$ \\
\hline $\mathrm{P}_{5}$ & $1218.13 \pm 114.11 b$ & $596.88 \pm 57.66 b$ & $622.26 \pm 59.01 \mathrm{a}$ & $0.96 \pm 0.08 b$ \\
\hline $\mathrm{P}_{6}$ & $1539.16 \pm 145.45 \mathrm{a}$ & $769.58 \pm 71.17 \mathrm{a}$ & $570.87 \pm 56.64$ a & $1.35 \pm 0.11 \mathrm{a}$ \\
\hline \multicolumn{5}{|l|}{ Pods } \\
\hline $\mathrm{P}_{1}$ & $144.52 \pm 11.78 \mathrm{f}$ & $40.46 \pm 3.94 \mathrm{f}$ & $104.46 \pm 9.19 \mathrm{e}$ & $0.39 \pm 0.04 \mathrm{~d}$ \\
\hline $\mathrm{P}_{2}$ & $206.99 \pm 19.57 \mathrm{e}$ & $74.51 \pm 6.94 \mathrm{e}$ & $132.88 \pm 14.04 \mathrm{~d}$ & $0.56 \pm 0.06 c$ \\
\hline $\mathrm{P}_{3}$ & $343.67 \pm 25.97 \mathrm{~d}$ & $134.02 \pm 10.87 \mathrm{~d}$ & $209.60 \pm 19.76 \mathrm{c}$ & $0.64 \pm 0.05 c$ \\
\hline $\mathrm{P}_{4}$ & $526.20 \pm 49.78 c$ & $231.53 \pm 19.88 c$ & $294.71 \pm 29.03 b$ & $0.79 \pm 0.06 \mathrm{~b}$ \\
\hline $\mathrm{P}_{5}$ & $1021.42 \pm 100.11 b$ & $439.84 \pm 40.26 \mathrm{~b}$ & $582.63 \pm 58.18 \mathrm{a}$ & $0.75 \pm 0.06 \mathrm{~b}$ \\
\hline $\mathrm{P}_{6}$ & $1265.17 \pm 111.25 \mathrm{a}$ & $594.63 \pm 47.07 \mathrm{a}$ & $671.43 \pm 69.42 \mathrm{a}$ & $0.89 \pm 0.07 \mathrm{a}$ \\
\hline \multicolumn{5}{|l|}{ Seeds } \\
\hline $\mathrm{P}_{1}$ & $295.59 \pm 21.49 \mathrm{f}$ & $70.93 \pm 6.44 \mathrm{e}$ & $225.02 \pm 25.59 \mathrm{e}$ & $0.32 \pm 0.02 \mathrm{a}$ \\
\hline $\mathrm{P}_{2}$ & $486.67 \pm 40.46 \mathrm{e}$ & $107.06 \pm 8.90 \mathrm{~d}$ & $379.33 \pm 39.01 \mathrm{~d}$ & $0.28 \pm 0.02 b$ \\
\hline $\mathrm{P}_{3}$ & $679.62 \pm 62.93 \mathrm{~d}$ & $135.92 \pm 10.43 c$ & $544.94 \pm 59.96 \mathrm{c}$ & $0.25 \pm 0.02 \mathrm{~b}$ \\
\hline $\mathrm{P}_{4}$ & $977.44 \pm 89.79 c$ & $175.93 \pm 13.88 b$ & $802.51 \pm 79.98 b$ & $0.22 \pm 0.02 c$ \\
\hline $\mathrm{P}_{5}$ & $1394.81 \pm 101.15 b$ & $195.27 \pm 16.86 b$ & $1200.47 \pm 115.18 \mathrm{a}$ & $0.16 \pm 0.01 \mathrm{~d}$ \\
\hline $\mathrm{P}_{6}$ & $1623.41 \pm 103.45 \mathrm{a}$ & $241.04 \pm 19.97 \mathrm{a}$ & $1383.57 \pm 126.72 \mathrm{a}$ & $0.17 \pm 0.01 \mathrm{~d}$ \\
\hline
\end{tabular}


The concentrations of lipidic P, proteic P, RNA-P and DNA-P and forms followed the same trend in all the organs studied, showing the highest value in green bean plants grown under the highest concentration of phosphorus supplied to the nutrient solution $\left(\mathrm{P}_{6}\right)$ (Table 4).

Table 4. Effects of different $P$ treatments on lipidic P, proteic P, RNA-P and DNA-P in roots, shoots, pods and seeds of green bean plants at the end of the experiment. $n=6$. Means \pm standard deviation within columns with different lower-case letters are significantly different at $p<0.05$ (One-way ANOVA and LSD tests).

\begin{tabular}{|c|c|c|c|c|}
\hline Treatments & $\begin{array}{c}\text { Lipidic } P \\
\left(\mathrm{mg} 100 \mathrm{~g}^{-1} \mathrm{DW}\right)\end{array}$ & $\begin{array}{c}\text { Proteic P } \\
\left(\mathrm{mg} 100 \mathrm{~g}^{-1} \mathrm{DW}\right)\end{array}$ & $\begin{array}{c}\text { RNA-P } \\
\left(\mathrm{mg} 100 \mathrm{~g}^{-1} \mathrm{DW}\right)\end{array}$ & $\begin{array}{c}\text { DNA-P } \\
\left(\mathrm{mg} 100 \mathrm{~g}^{-1} \mathrm{DW}\right)\end{array}$ \\
\hline \multicolumn{5}{|l|}{ Roots } \\
\hline $\mathrm{P}_{1}$ & $34.63 \pm 3.17 \mathrm{e}$ & $17.33 \pm 1.70 \mathrm{f}$ & $24.76 \pm 2.19 \mathrm{e}$ & $19.81 \pm 1.18 \mathrm{e}$ \\
\hline $\mathrm{P}_{2}$ & $69.11 \pm 5.45 \mathrm{~d}$ & $21.26 \pm 2.23 \mathrm{e}$ & $47.84 \pm 4.55 \mathrm{~d}$ & $37.21 \pm 2.83 \mathrm{~d}$ \\
\hline $\mathrm{P}_{3}$ & $82.35 \pm 7.42 c$ & $27.45 \pm 2.54 \mathrm{~d}$ & $54.90 \pm 5.60 \mathrm{~d}$ & $41.17 \pm 3.59 \mathrm{~d}$ \\
\hline $\mathrm{P}_{4}$ & $95.37 \pm 8.26 \mathrm{c}$ & $47.68 \pm 4.06 \mathrm{c}$ & $85.94 \pm 7.92 \mathrm{c}$ & $57.22 \pm 4.58 c$ \\
\hline $\mathrm{P}_{5}$ & $135.70 \pm 12.01 \mathrm{~b}$ & $60.31 \pm 5.38 b$ & $135.70 \pm 12.12 b$ & $75.39 \pm 7.39 b$ \\
\hline $\mathrm{P}_{6}$ & $170.79 \pm 14.19 \mathrm{a}$ & $83.77 \pm 8.22 \mathrm{a}$ & $170.79 \pm 13.54 \mathrm{a}$ & $93.77 \pm 7.23 \mathrm{a}$ \\
\hline \multicolumn{5}{|l|}{ Shoots } \\
\hline $\mathrm{P}_{1}$ & $25.06 \pm 1.84 \mathrm{f}$ & $13.36 \pm 1.31 \mathrm{e}$ & $18.37 \pm 1.59 \mathrm{e}$ & $15.03 \pm 1.07 \mathrm{e}$ \\
\hline $\mathrm{P}_{2}$ & $42.49 \pm 3.24 \mathrm{e}$ & $14.16 \pm 1.40 \mathrm{e}$ & $35.41 \pm 3.04 \mathrm{~d}$ & $28.32 \pm 1.97 \mathrm{~d}$ \\
\hline $\mathrm{P}_{3}$ & $58.37 \pm 4.64 \mathrm{~d}$ & $22.45 \pm 2.01 \mathrm{~d}$ & $40.41 \pm 3.96 \mathrm{~d}$ & $31.43 \pm 2.09 \mathrm{~d}$ \\
\hline $\mathrm{P}_{4}$ & $89.70 \pm 7.88 c$ & $48.93 \pm 4.08 \mathrm{c}$ & $81.55 \pm 7.88 c$ & $57.08 \pm 4.86 c$ \\
\hline $\mathrm{P}_{5}$ & $121.81 \pm 11.01 \mathrm{~b}$ & $73.08 \pm 6.86 b$ & $121.81 \pm 11.18 b$ & $85.26 \pm 8.04 b$ \\
\hline $\mathrm{P}_{6}$ & $169.30 \pm 14.07 \mathrm{a}$ & $107.73 \pm 10.07 \mathrm{a}$ & $153.91 \pm 12.89 \mathrm{a}$ & $107.73 \pm 9.26 \mathrm{a}$ \\
\hline \multicolumn{5}{|l|}{ Pods } \\
\hline $\mathrm{P}_{1}$ & $20.23 \pm 1.44 \mathrm{~d}$ & $13.00 \pm 1.04 \mathrm{e}$ & $15.89 \pm 1.35 \mathrm{f}$ & $14.45 \pm 1.49 \mathrm{f}$ \\
\hline $\mathrm{P}_{2}$ & $22.76 \pm 1.24 \mathrm{~d}$ & $14.48 \pm 1.11 \mathrm{e}$ & $20.69 \pm 1.86 \mathrm{e}$ & $18.62 \pm 1.71 \mathrm{e}$ \\
\hline $\mathrm{P}_{3}$ & $41.23 \pm 3.87 c$ & $27.49 \pm 2.57 \mathrm{~d}$ & $34.36 \pm 2.96 \mathrm{~d}$ & $30.92 \pm 2.80 \mathrm{~d}$ \\
\hline $\mathrm{P}_{4}$ & $47.35 \pm 4.18 \mathrm{c}$ & $47.35 \pm 3.88 c$ & $57.88 \pm 5.08 c$ & $47.35 \pm 4.02 c$ \\
\hline $\mathrm{P}_{5}$ & $81.71 \pm 6.86 \mathrm{~b}$ & $91.92 \pm 8.81 \mathrm{~b}$ & $112.35 \pm 10.16 b$ & $91.92 \pm 9.01 \mathrm{~b}$ \\
\hline $\mathrm{P}_{6}$ & $139.16 \pm 12.14 \mathrm{a}$ & $111.21 \pm 9.99 \mathrm{a}$ & $126.51 \pm 11.41 \mathrm{a}$ & $111.21 \pm 9.55 \mathrm{a}$ \\
\hline \multicolumn{5}{|l|}{ Seeds } \\
\hline $\mathrm{P}_{1}$ & $23.64 \pm 1.51 \mathrm{f}$ & $11.82 \pm 0.94 \mathrm{e}$ & $17.73 \pm 1.04 \mathrm{f}$ & $11.82 \pm 1.12 \mathrm{e}$ \\
\hline $\mathrm{P}_{2}$ & $34.06 \pm 2.14 \mathrm{e}$ & $19.46 \pm 1.52 \mathrm{~d}$ & $29.19 \pm 2.04 \mathrm{e}$ & $24.33 \pm 2.01 \mathrm{~d}$ \\
\hline $\mathrm{P}_{3}$ & $47.57 \pm 3.95 \mathrm{~d}$ & $27.18 \pm 2.17 \mathrm{c}$ & $40.77 \pm 3.47 \mathrm{~d}$ & $33.98 \pm 2.90 c$ \\
\hline $\mathrm{P}_{4}$ & $78.19 \pm 6.18 c$ & $48.87 \pm 4.47 \mathrm{~b}$ & $55.64 \pm 5.13 c$ & $58.64 \pm 4.63 \mathrm{~b}$ \\
\hline $\mathrm{P}_{5}$ & $97.63 \pm 8.24 b$ & $55.79 \pm 5.16 b$ & $69.73 \pm 6.18 b$ & $69.73 \pm 6.11 b$ \\
\hline $\mathrm{P}_{6}$ & $133.63 \pm 11.17 \mathrm{a}$ & $69.93 \pm 5.57 \mathrm{a}$ & $88.16 \pm 7.54 \mathrm{a}$ & $84.16 \pm 7.45 \mathrm{a}$ \\
\hline
\end{tabular}

Regarding acid phosphatase activity, the trend was the opposite with respect to the different forms of $\mathrm{P}$ assessed in all the organs studied, with the control treatment $\left(\mathrm{P}_{1}\right)$ showing the highest value (Figure 3).

The concentrations of phytates in seeds increased under increasing phosphorus supply to the nutrient solution, showing the highest values in green bean plants grown under $\mathrm{P}_{5}$ and $\mathrm{P}_{6}$ treatments (Figure 4 ). 


\section{$\square \mathrm{P} 1 \square \mathrm{P2} \square \mathrm{P3} \square \mathrm{P4} \square \mathrm{P5} \square \mathrm{P6}$}

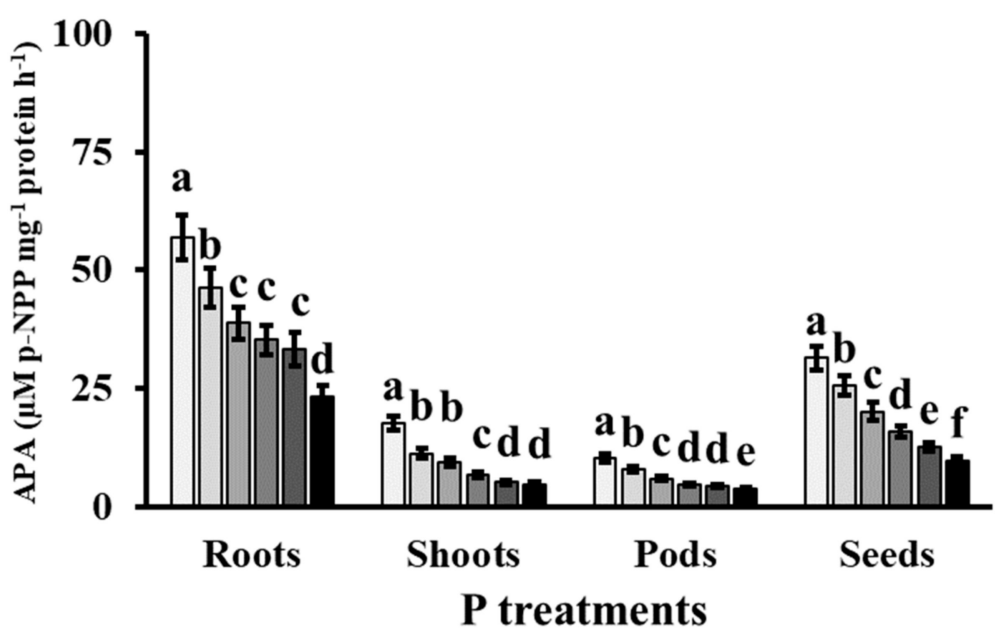

Figure 3. Effects of different $P$ treatments on acid phosphatase activity in roots, shoots, pods and seeds of green bean plants at the end of the experiment. Means with the same lower-case letter are not significantly different at $p<0.05$ according to LSD and one-way ANOVA. Error bars represent standard deviation of the means (SE), $n=6$.

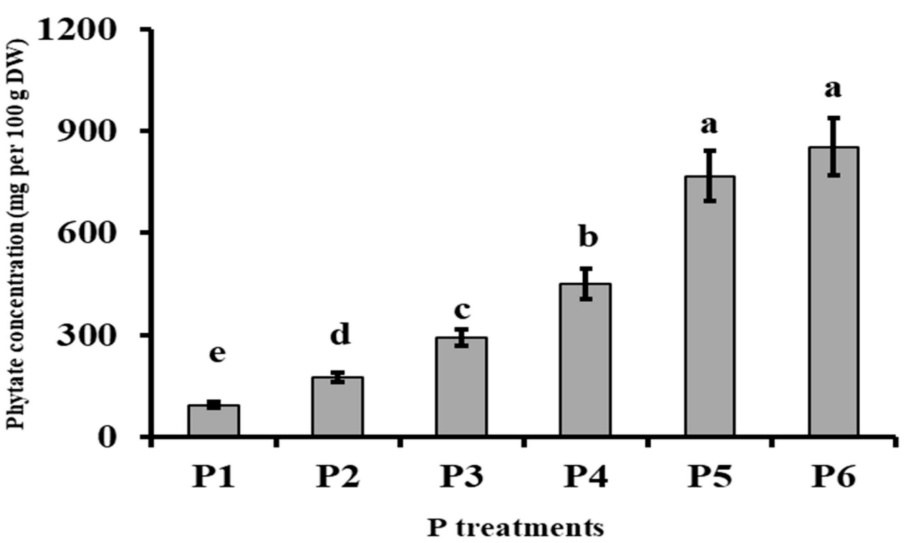

Figure 4. Effects of different $P$ treatments on phytate concentration in seeds of green bean plants at the end of the experiment. Means with the same lower-case letter are not significantly different at $p<$ 0.05 according to LSD and one-way ANOVA. Error bars represent standard deviation of the means (SE), $n=6$.

Comparing the relationships between the different $\mathrm{P}$-forms and the concentration of $\mathrm{P}$ supplied to the nutrient solution, the highest slope for lipidic and RNA-P fractions and the lowest for phytates can be highlighted. It is also necessary to point out that there was a high positive correlation in all cases, being especially close to 1 in RNA-P and DNA-P (Table 5).

Table 5. Relationship between the different forms of $\mathrm{P}$ and the concentration of $\mathrm{P}$ supplied to the nutrient solution.

\begin{tabular}{cc}
\hline Regression Equation & $\mathbf{R}^{\mathbf{2}}$ \\
\hline Organic $\mathrm{P}=0.13 \mathrm{P}+1.21$ & 0.94 \\
Lipidic P $=0.09 \mathrm{P}+0.31$ & 0.97 \\
Proteic $\mathrm{P}=0.07 \mathrm{P}-0.15$ & 0.97 \\
RNA-P $=0.09 \mathrm{P}-0.04$ & 0.99 \\
DNA-P $=0.07 \mathrm{P}+0.10$ & 0.99 \\
Phytates $=0.03 \mathrm{P}+0.02$ & 0.92 \\
\hline
\end{tabular}




\section{Discussion}

Several works have demonstrated that the growth of green bean plants under phosphorus deficit conditions results in a decline in dry weight in the aerial part of the plant and an increase in the root system $[29,44]$. In our experiment, the highest root growth under the lowest $\mathrm{P}$ concentration can be ascribed to the growth of long root hairs to improve $\mathrm{P}$ acquisition [45]. Nevertheless, the high values of shoot and pod dry weight under $\mathrm{P}_{3}$ and $\mathrm{P}_{4}$ treatments, and the consequent decrease at higher levels of $\mathrm{P}$, differ from the results obtained by previous researchers $[46,47]$. The apparently contradictory results obtained in our experiment can be attributed to the longer duration imposed in our treatments. Moreover, our results suggest that levels of $\mathrm{P}$ greater than $4 \mathrm{mM}$ may be toxic, or excessive, for adequate plant growth and hence shoot and pod dry weight decreased under the highest $P$ treatments.

The results obtained in our experiment report higher concentrations of glucose, fructose, sucrose, and starch in shoots than in roots at the end of the experimental period. Nevertheless, it is necessary to point out that increasing doses of $\mathrm{P}$ in the nutrient solution resulted only in a remarkable increase in soluble sugars (fructose, glucose, and sucrose) in roots, especially in plants grown under $\mathrm{P}_{3}$ and $\mathrm{P}_{4}$. These results suggest an alteration of source/sink balance under different $P$ levels ( $P$ deficiency in $P_{1}$ and $P_{2}$ and $P$ excess in $P_{5}$ and $\mathrm{P}_{6}$ ) as reported by Passarinho et al. [48]. The increase in soluble sugars in roots in green bean plants can be ascribed to the greater translocation from the aerial part to roots [26], a higher rate of hydrolysis of sucrose [27], and a decline in hexose phosphorylation [44]. It may also be due to energy consumption by the roots, which in the case of $\mathrm{P}$ deficit can be related to the active P uptake [49], and in the case of excess, with the maintenance of the cytoplasmic osmotic potential of the root cells [50]. In our experiment, the lack of variations in starch concentration in roots and shoots of green bean under increasing $\mathrm{P}$ concentration levels in the nutrient solution was not in line with previous findings noted by other researchers such as Fredeen et al. [51] and Rao et al. [52], who reported an increase in starch concentrations in organs of soybean and sugar beet under P increase, respectively. The excessive application of $\mathrm{P}$ can result in negative effects in chloroplasts, since they are involved in the exchange of triose $\mathrm{P}$ and other phosphorylated metabolites against phosphate; therefore, if the levels of $\mathrm{P}$ are too high, this may cause a depletion of the activity of this organelle in metabolites, which could affect photosynthesis (breakdown of RPPP) or transitory starch.

As far as enzymatic activities were concerned, the homeostasis of sugars in the different organs of a plant is controlled through different enzymes aiming to control the biosynthesis and degradation of soluble sugars according to the requirements of the plant. In the same vein, Ho et al. [53] reported that differences in enzymatic activities related to sucrose metabolism depended on the activity of the sucrose-degrading enzymes inside the sink, since they are responsible for the capacity of the sink organ to import assimilates and thus sink strength. With respect to P supply, we reported the same trend in the roots and shoots of sucrose biosynthesis enzymes (SPS and F1,6BPase) and sucrose degradation via SS activities. The highest activity was presented under $\mathrm{P}_{3}$ treatment, decreasing under deficit, insufficient, and excessive $P$ supply. Nevertheless, it is necessary to point out a different trend in the biosynthesis and degradation of sucrose in the roots and shoots of green bean plants related to invertase activity. In roots, there was a similar trend with respect to the other enzymes, also suggesting a decrease in sugar metabolism under $\mathrm{P}$ deficit and excess conditions. Nevertheless, in shoots, there was no clear trend under increasing P supply to the nutrient solution.

The enzymes SPS and F1,6BPase participate in sucrose biosynthesis in the cytosol of the cell from triose-P, with SPS being the main enzyme responsible for the regulation of this biosynthesis [54]. Our results may suggest that in these treatments, both enzymes were involved in the biosynthesis of sucrose in roots.

The results obtained in our experiment report that the degradation of sucrose in shoots through the SS pathway can be related to the reduction in the energy of the invertase 
pathway to break down sucrose into two molecules of Fru-6-P, as reported by Black et al. [55]. In addition, the participation of SS in sucrose degradation could be due to this enzyme's relationship with vascular tissues and its presence in the adjacent cells, as noted by Ciereszko et al. [26]. This may be justified by their function in hydrolysis and sucrose unloading via the phloem in the developing parts of green bean [27]. At root level, these results may suggest that phloem unloading was occurring via the symplast [56]. On the other hand, the higher activity of acid or alkaline invertases could be associated with the stage of the growing organs, since alkaline invertase is more crucial for sucrose breakdown, which occurs under P deficit treatments, while acidic invertase is more active in less-developed organs, which occurs under excess $P$ treatments [57].

With regard to total $P$, the accumulation in all the organs of green beans under increasing doses of $\mathrm{P}$ in the nutrient solution agrees with the results reported by Thao et al. [58] who noted the same trend in lettuce. It is necessary to point out that in our experiment, there was a high correlation between the different fractions of $\mathrm{P}$ assessed and the increasing doses of $\mathrm{P}$ in the nutrient solution. Reviewing the previous literature, there are several references indicating that under increasing $\mathrm{P}$ concentration levels to the nutrient solution, $\mathrm{P}$ concentration increased in the different fractions assessed, as well as in the different organs studied in green beans [59-61], and in other crops such as wheat [62] and cucumber [63].

Inorganic $\mathrm{P}$ concentration in all the organs assessed in our experiment showed the same trend as the total $\mathrm{P}$ concentration. Considering the results obtained, it can be suggested that under increasing doses of $\mathrm{P}$ in the nutrient solution, green beans plants may have upregulated several genes involved in the activity of low affinity Pi transporters responsible for Pi uptake under increasing concentrations of $\mathrm{P}$ in the nutrient solution, as noted by Nussaume et al. [64] and Gu et al. [65]. Analogously, the highest concentration of inorganic $\mathrm{P}$ in the different sections, assessed under the highest concentration of $\mathrm{P}$ in the nutrient solution, can be due to the role of this fraction as a reserve for phosphorus which can be used by the plant during times of higher rate synthesis of new chemical compounds [66].

As far as organic $\mathrm{P}$ was concerned, the highest concentration of this $\mathrm{P}$ fraction in plants grown under $\mathrm{P}_{6}$ treatment suggests that there was an increase in nucleic acids and phospholipids under increasing P supply, as has been reported previously by Bieleski [12] in green bean plants. In our experiment, the increasing values of the organic $\mathrm{P} /$ inorganic $\mathrm{P}$ ratio in roots, shoots, and pods under increasing $\mathrm{P}$ supply in the nutrient solution suggest an efficient conversion of inorganic $P$ into organic $P$ for their consecutive use in the synthesis of phosphorous compounds, as reported by Lambers and Plaxton [67]. In the case of seeds, the decrease in the ratio under increasing P supply can be ascribed to the accumulation of organic $P$ in the form of phytates [68].

Nevertheless, the $\mathrm{P}$ level in the different organs can be evaluated through different $P$ pools [12]. In our experiment, we assessed the lipidic P, proteic P, RNA-P and DNA-P fractions in the different fractions of the plants: roots, shoots, pods and seeds as well as the phytates in pods. Considering the lipidic $P$ fraction, our results show that the highest levels of $\mathrm{P}$ in the nutrient solution resulted in the highest concentration of lipidic $\mathrm{P}$ in all the organs assessed. This fact can be ascribed to the higher presence of $\mathrm{Pi}$, as occurred in the $\mathrm{P}_{6}$ treatment, since one strategy to achieve Pi from internal sources is the degradation of biological molecules with Pi. In plants, the activation of phospholipases to hydrolyze phospholipids and the release of Pi is common [14].

Organic $\mathrm{P}$ is a crucial element in the chemical composition of nucleic acids (DNA and RNA) [69]. In our experiment, the different organs assessed in green beans had the highest concentration of DNA and RNA in plants grown under the highest application of $\mathrm{P}$. The highest DNA concentration can be related to the overexpression of several Presponsive genes, responsible for phosphate transporter accumulation and phosphatases, as reported by Tian et al. [70]. In the case of RNA, the highest value in plants grown under $\mathrm{P}_{6}$ treatment could be due to the enhancement of protein synthesis under increasing $\mathrm{P}$ supply to the plant [71,72]. In our experiment, the highest concentration of proteic-P in 
plants grown under the highest $\mathrm{P}$ supply to the nutrient solution can be related to the previously mentioned protein biosynthesis increase. Although the application of increasing concentrations of $\mathrm{P}$ in the nutrient solution resulted in a consequent increase in $\mathrm{P}$ in all the forms and organs assessed, it could be possible that the excess of application changed several biological pathways with a crucial role in the growth of the plants, resulting in the decline in dry weight. Moreover, the increase in P uptake may suggest the presence of high and low-affinity transporters in green bean plants. The high affinity transporter whose activity was enhanced under low P supply and the low affinity transporter working at high P supply with a constitutive activity.

Acid phosphatases participate in several metabolic and bioenergetics processes at the cellular level, such as the uptake, allocation, and recycling of Pi. The expression of APase genes is affected by different environmental factors [73]. Reviewing the previous literature, there are several studies reporting that the activity of phosphatase acids can be enhanced under P deficiency in green beans [74], as well as in other crops such as lupinus [75], white clover [76], and wheat [77]. Nevertheless, our results reveal that under increasing P supply to green beans, the activity of phosphatase acid decreased in the different organs assessed. This fact can be explained because the decline in the activity of phosphatase acid responsible for the hydrolysis of Pi from phosphate-monoesters, such as nucleic acids and phospholipids [78], increased the concentration of several fractions of P, such as lipidic, DNA, and RNA fractions.

In our experiment, the concentrations of phytates in seeds increased under increasing phosphorus supply in the nutrient solution. These results are in line with previous findings reported by Lockhart and Hurt [79], who noted that the phytate concentration was highly correlated with phosphorus levels. High amounts of P in seeds is also crucial for their formation and development [80]. This increase in phytates in seeds can be ascribed to a reduction in the activity of chalcone isomerase (CHI) and phenylalanine ammonia-lyase (PAL), as reported by Chen et al. [81]. The negative effect of excess consumption of phytate in the human diet is worth mentioning, especially in vegetarians, since it is considered an anti-nutrient associated with low absorption of other nutrients such as $\mathrm{Ca}, \mathrm{Cu}, \mathrm{Fe}$, $\mathrm{Zn}$ and $\mathrm{Mn}$, resulting in negative nutritional well-being [82]. Moreover, the acceptable threshold of phytate concentration established by the FAO for green beans is $358 \mathrm{mg} / 100 \mathrm{~g}$ DW [83], therefore nutrition with green beans grown under $\mathrm{P}_{4}, \mathrm{P}_{5}$, and $\mathrm{P}_{6}$ treatments is not recommended. The increase in phytates in seeds can be associated with the fact that when the rate of Pi uptake is excessive, plants tend to prevent the accumulation of toxic Pi concentrations which can be carried out through the conversion of the inorganic form of $\mathrm{P}$ into organic storage compounds like phytates. Therefore, it would be recommendable to perform the fertigation of green beans with phosphorus concentrations below to $4 \mathrm{mM}$ in order to avoid nutritional disorders and also a reduction in yield in this species.

\section{Conclusions}

The increase in $\mathrm{P}$ dose in the nutrient solution supplied to green bean reduced shoot dry weight, and the highest values for shoot and pod dry weight were in green beans plants grown under $\mathrm{P}_{3}$ and $\mathrm{P}_{4}$ treatments. After sixty days of sowing, increasing $\mathrm{P}$ supply in the nutrient solution resulted in higher concentrations of glucose, fructose, sucrose, and starch in the shoots compared to the roots of green bean plants. Non-structural carbohydrates (glucose, fructose and sucrose) showed the highest value in the roots in green bean plants grown under $\mathrm{P}_{3}$ and $\mathrm{P}_{4}$, whereas in shoots, they remained constant and lower than the control treatment under increasing $\mathrm{P}$ supply. With regard to starch, the concentration in roots and shoots did not change under different $\mathrm{P}$ doses. Considering the enzymatic activities related to the biosynthesis and degradation of soluble sugars, it is necessary to point out different trends in the roots and shoots for invertases. The increase in P supply to the nutrient solution resulted in an increase in the concentration of the different forms assessed for $\mathrm{P}$ in all the organs studied. Under increasing $\mathrm{P}$ supply, acid phosphatase activity declined in all the organs assessed, whereas seed phytate concentration increased. 
These results corroborate the significance of studying the physiological responses of $\mathrm{P}$ supply to select the most adequate $\mathrm{P}$ concentration for the growth of green bean plants, since human nutrition with green beans grown under $\mathrm{P}_{4}, \mathrm{P}_{5}$, and $\mathrm{P}_{6}$ treatments is not recommended.

Author Contributions: Conceptualization, M.T.L.; data curation, P.G.-C. and P.P.-R.; formal analysis, E.S.; investigation, P.G.-C. and E.S.; project administration, M.T.L.; supervision, M.T.L.; writingoriginal draft, P.G.-C. and E.S. All authors have read and agreed to the published version of the manuscript.

Funding: This research received no external funding.

Institutional Review Board Statement: Not applicable.

Informed Consent Statement: Not applicable.

Data Availability Statement: Not applicable.

Acknowledgments: The authors thank the funding of this work by the group AGR-242 from University of Almería (Sustainability of Horticultural and Ornamental Protected Systems).

Conflicts of Interest: The authors declare no conflict of interest.

\section{References}

1. Zafar, M.; Abbasi, M.K.; Rahim, N.; Khaliq, A.; Shaheen, A.; Jamil, M.; Shahid, M. Influence of integrated phosphorus supply and plant growth promoting rhizobacteria on growth, nodulation, yield and nutrient uptake in Phaseolus vulgaris. Afr. J. Biotechol. 2011, 10, 16781-16792.

2. Myers, J.R.; Kmiecik, K. Common bean: Economic importance and relevance to biological science research. In The Common Bean Genome; Springer: Cham, Switzerland, 2017; pp. 1-20.

3. Food and Agriculture Organization of the United Nations (FAO). FAO Statistics. 2018. Available online: http:/ /www.fao.org/ faostat/en/\#home (accessed on 30 November 2020).

4. Pizzeghello, D.; Berti, A.; Nardi, S.; Morari, F. Phosphorus forms and P-sorption properties in three alkaline soils after long-term mineral and manure applications in north-eastern Italy. Agric. Ecosyst. Environ. 2011, 141, 58-66. [CrossRef]

5. Pizzeghello, D.; Berti, A.; Nardi, S.; Morari, F. Relationship between soil test phosphorus and phosphorus release to solution in three soils after long-term mineral and manure application. Agric. Ecosyst. Environ. 2016, 233, 214-223. [CrossRef]

6. Saad, S.; Lam-Son, P.T. Legume Nitrogen Fixation in Soils with Low Phosphorus Availability; Springer: Berlin/Heidelberg, Germany, 2017; p. 286.

7. Vance, C.P.; Uhde-Stone, C.; Allan, D.L. Phosphorus acquisition and use: Critical adaptations by plants for securing a nonrenewable resource. New Phytol. 2003, 157, 423-447. [CrossRef]

8. Yang, X.J.; Finnegan, P.M. Regulation of phosphate starvation responses in higher plants. Ann. Bot. 2010, 105, 513-526. [CrossRef]

9. Hansen, J.C.; Cade-Menun, B.J.; Strawn, D.G. Phosphorus speciation in manure-amended alkaline soils. J. Environ. Qual. 2004, 33, 1521-1527. [CrossRef]

10. Turner, B.L.; Richardson, A.E.; Mullaney, E.J. Inositol Phosphates: Linking Agriculture and the Environment; CAB International: Wallingford, UK, 2007; p. 304.

11. Raghothama, K.G. Phosphate acquisition. Ann. Rev. Plant Physiol. Plant Mol. Biol. 1999, 50, 665-693. [CrossRef]

12. Bieleski, R.L. Phosphate pools, phosphate transport, and phosphate availability. Ann. Rev. Plant. Physiol. 1973, $24,225-252$. [CrossRef]

13. Maathuis, F.J.M. Physiological functions of mineral macronutrients. Curr. Opin. Plant Biol. 2009, 12, 250-258. [CrossRef]

14. Plaxton, W.C.; Tran, H.T. Metabolic adaptations of phosphate-starved plants. Plant Physiol. 2011, 156, 1006-1015. [CrossRef]

15. Pang, J.; Ryan, M.H.; Lambers, H.; Siddique, K.H. Phosphorus acquisition and utilisation in crop legumes under global change. Curr. Opin. Plant Biol. 2018, 45, 248-254. [CrossRef] [PubMed]

16. Rees, T. Compartmentation of plant metabolism. In The Biochemistry of Plants; Davies, D.D., Ed.; Academic Press: San Diego, CA, USA, 1987; Volume 12: Physiology of, Metabolism, pp. 87-115.

17. Wind, J.; Smeekens, S.; Hanson, J. Sucrose: Metabolite and signaling molecule. Phytochemistry 2010, 71, 1610-1614. [CrossRef]

18. MacRae, E.; Lunn, J. Control of sucrose biosynthesis. Ann. Plant. Rev. 2018, 22, 234-257.

19. Tauzin, A.S.; Giardina, T. Sucrose and invertases, a part of the plant defense response to the biotic stresses. Front. Plant Sci. 2014, 5, 293. [CrossRef]

20. Xu, X.; Yang, Y.; Liu, C.; Sun, Y.; Zhang, T.; Hou, M.; Huang, S.; Yuan, H. The evolutionary history of the sucrose synthase gene family in higher plants. BMC Plant Biol. 2019, 19,1-14. [CrossRef]

21. Granot, D.; Stein, O. An overview of sucrose synthases in plants. Front. Plant Sci. 2019, 10, 95.

22. Wan, H.; Wu, L.; Yang, Y.; Zhou, G.; Ruan, Y.L. Evolution of sucrose metabolism: The dichotomy of invertases and beyond. Trends Plant Sci. 2018, 23, 163-177. [CrossRef] 
23. Jin, J.; Tang, C.; Sale, P. The impact of elevated carbon dioxide on the phosphorus nutrition of plants: A review. Ann. Bot. 2015, 116, 987-999. [CrossRef]

24. Raven, J.A.; Lambers, H.; Smith, S.E.; Westoby, M. Costs of acquiring phosphorus by vascular land plants: Patterns and implications for plant coexistence. New Phytol. 2018, 217, 1420-1427. [CrossRef]

25. Khan, M.S.; Zaidi, A.; Ahmad, E. Mechanism of phosphate solubilization and physiological functions of phosphate-solubilizing microorganisms. In Phosphate Solubilizing Microorganisms; Springer: Cham, Switzerland, 2014; pp. 31-62.

26. Ciereszko, I.; Gniazdowska, A.; Mikulska, M.; Rychter, A.M. Assimilate translocation in bean plants (Phaseolus vulgaris L.) during phosphate deficiency. J. Plant Physiol. 1996, 149, 343-348. [CrossRef]

27. Ciereszko, I.; Zambrzycka, A.; Rychter, A.M. Sucrose hydrolysis in bean roots (Phaseolus vulgaris L.) under phosphate deficiency. Plant Sci. 1998, 133, 139-144. [CrossRef]

28. Ciereszko, I.; Miłosek, I.; Rychter, A.M. Assimilate distribution in bean plants (Phaseolus vulgaris L.) during phosphate limitation. Acta Soc. Bot. Pol. 1999, 68, 269-273. [CrossRef]

29. Ciereszko, I.; Barbachowska, A. Sucrose metabolism in leaves and roots of bean (Phaseolus vulgaris L.) during phosphate deficiency. J. Plant Physiol. 2000, 156, 640-644. [CrossRef]

30. Wolf, B. A comprehensive system of leaf analysis and its use for diagnosing crop nutrient status. Commun. Soil Sci. Plant Anal. 1982, 13, 1035-1059. [CrossRef]

31. Irigoyen, J.J.; Emerich, D.W.; Sánchez-Díaz, M. Water stress induced changes in the concentrations of proline and total soluble sugars in nodulated alfalfa (Medicago sativa) plants. Physiol. Plant 1992, 8, 455-460. [CrossRef]

32. Hubbard, N.L.; Huber, S.C.; Pharr, D.M. Sucrose phosphate synthase and acid invertase as determinants of sucrose concentration in developing muskmelon (Cucumis melo L.) fruits. Plant Physiol. 1989, 91, 1527-1534. [CrossRef]

33. Bradford, M.M. A rapid and sensitive method for the quantification of microgram quantities of protein utilizing the principle of protein-dye binding. Anal. Biochem. 1976, 72, 248-254. [CrossRef]

34. Cheikh, N.; Brenner, M.L. Regulation of key enzymes of sucrose biosynthesis in soybean leaves. Plant Physiol. 1992, 100, 1230-1237. [CrossRef]

35. Van Handel, E. Direct microdetermination of sucrose. Anal. Biochem. 1968, 22, 280-283. [CrossRef]

36. Holaday, S.A.; Martindale, W.; Alred, R.; Brooks, A.L.; Leegood, R.C. Changes in activities of enzymes of carbon metabolism in leaves during exposure of plants to low temperature. Plant Physiol. 1992, 98, 1105-1114. [CrossRef]

37. Geladopoulus, T.P.; Sotiroudis, T.G.; Evangelopoulus, A.E. A malachite green colorimetric assay for protein phosphatase activity. Anal. Biochem. 1991, 192, 112-116. [CrossRef]

38. Miller, G.L. Use of dinitrosalicylic acid reagent for determination of reducing sugar. Anal. Chem. 1959, 31, 426-428. [CrossRef]

39. Hogue, E.; Wilcow, G.E.; Cantlife, D.J. Effect of soil P on phosphate fraction in tomato leaves. J. Am. Soc. Hortic. Sci. 1970, 95, 174-176.

40. López-Cantarero, I.; Ruiz, J.M.; Hernández, J.; Romero, L. Phosphorus metabolism and yield response to increases in nitrogenphosphorus fertilization: Improvement in greenhouse cultivation of eggplant (Solanum melongena cv. Bonica). J. Agric. Food. Chem. 1998, 46, 1603-1608. [CrossRef]

41. Besford, R.T. Phosphorus nutrition and acid phosphatase activity in leaves of seven plant species. J. Sci. Food Agric. 1979, 30, 282-285. [CrossRef]

42. Ruiz, J.M.; Belakbir, A.; Romero, L. Foliar level of phosphorus and its bioindicators in Cucumis melo grafted plants. A possible effect of rootstock. J. Plant Physiol. 1996, 149, 400-404. [CrossRef]

43. Graf, E.; Dintzis, F.R. High-performance liquid chromatographic method for the determination of phytate. Anal. Biochem. 1982, 119, 413-417. [CrossRef]

44. Rychter, A.M.; Randall, D.D. The effect of phosphate deficiency on carbohydrate metabolism in bean roots. Physiol. Plant 1994, 91, 383-388. [CrossRef]

45. Zhu, J.; Zhang, C.; Lynch, J.P. The utility of phenotypic plasticity of root hair length for phosphorus acquisition. Funct. Plant Biol. 2010, 37, 313-322. [CrossRef]

46. Pieters, A.J.; Paul, M.J.; Lawlor, D.W. Low sink demand limits photosynthesis under Pi deficiency. J. Exp. Bot. 2001, 52, 1083-1091. [CrossRef]

47. Warren, C.R.; Adams, M.A. Phosphorus affects growth and partitioning of nitrogen to Rubisco in Pinus pinaster. Tree Physiol. 2002, 22, 11-19. [CrossRef] [PubMed]

48. Passarinho, J.A.; Rodrigues, M.L.; Osorio, M.L.; Ricardo, C.P.; Chaves, M.M. Physiological responses of Lupinus mutabilis to phosphorus nutrition and season of growth. J. Plant. Nutr. 2000, 23, 487-505. [CrossRef]

49. Mengel, K.; Kirkby, E.A. Principles of Plant Nutrition; Kluwer Academic Publishers: Dordrecht, The Netherlands, 2001; 849p.

50. Marschner, H. Mineral Nutrition of Higher Plants; Acaemic Press: London, UK, 2011; 645p.

51. Fredeen, A.L.; Rao, I.M.; Terry, N. Influence of phosphorus nutrition on growth and carbon partitioning in Glycine max. Plant Physiol. 1989, 89, 225-230. [CrossRef]

52. Rao, I.M.; Fredeen, A.L.; Terry, N. Leaf phosphate status, photosynthesis, and carbon partitioning in sugar beet III. Diurnal changes in carbon partitioning and carbon export. Plant Physiol. 1990, 92, 29-36. [CrossRef] [PubMed] 
53. Ho, L.C.; Lecharny, A.; Willenbrink, J. Sucrose cleavage in relation to import and metabolism of sugars in sink organs. In Phloem Transport and Assimilate Compartmentation; Bonneman, J.L., Delrot, S., Lucas, W.J., Danty, J., Eds.; Intercept Ltd.: Andover, UK, 1991; pp. 178-186.

54. Stitt, M.; Herzog, B.; Heldt, H.W. Control of photosynthetic sucrose synthesis by fructose 2,6-bisphosphate, I: Coordination of $\mathrm{CO}_{2}$ fixation and sucrose synthesis. Plant Physiol. 1981, 75, 548-553. [CrossRef]

55. Black, C.C.; Mustardy, L.; Sung, S.S.; Kormanik, P.P.; Xu, D.P.; Paz, N. Regulation and roles for alternative pathways of hexose metabolism in plants. Physiol. Plant 1987, 69, 387-394. [CrossRef]

56. Ross, H.A.; Davies, H.V. Purification and characterization of sucrose synthase from the cotyledons of Vicia faba L. Plant Physiol. 1992, 100, 1008-1013. [CrossRef]

57. Schaffer, A.A. Invertases in young and mature leaves of Citrus sinensis. Phytochemistry 1986, 25, 2275-2277. [CrossRef]

58. Thao, H.T.B.; Yamakawa, T.; Shibata, K. Effect of phosphite-phosphate interaction on growth and quality of hydroponic lettuce (Lactuca sativa). J. Plant. Nutr. Soil Sci. 2009, 172, 378-384. [CrossRef]

59. Gidago, G.; Beyene, S.; Worku, W.; Sodo, E. The response of haricot bean (Phaseolus vulgaris L.) to phosphorus application on Ultisols at Areka, Southern Ethiopia. J. Biol. Agric. Healthc. 2011, 1, 38-49.

60. Ávila, F.W.; Faquin, V.; da Silva Lobato, A.K.; Ávila, P.A.; Marques, D.J.; Silva Guedes, E.M.; Tan, D.K.Y. Effect of phosphite supply in nutrient solution on yield, phosphorus nutrition and enzymatic behavior in common bean (Phaseolus vulgaris L.) plants. Austr. J. Crop. Sci. 2013, 7, 713.

61. Gulmezoglu, N.; Daghan, H. The interactive effects of phosphorus and salt on growth, water potential and phosphorus uptake in green beans. Appl. Ecol. Environ. Res. 2017, 15, 1831-1842. [CrossRef]

62. Hussain, A.; Larsson, H.; Kuktaite, R.; Johansson, E. Mineral composition of organically grown wheat genotypes: Contribution to daily minerals intake. Inter. J. Environ. Res. Public Health 2010, 7, 3442-3456. [CrossRef] [PubMed]

63. Constan-Aguilar, C.; Sánchez-Rodríguez, E.; Rubio-Wilhelmi, M.M.; Camacho, M.A.; Romero, L.; Ruiz, J.M.; Blasco, B. Physiological and nutritional evaluation of the application of phosphite as a phosphorus source in cucumber plants. Commun. Soil Sci. Plant. Anal. 2014, 45, 204-222. [CrossRef]

64. Nussaume, L.; Kanno, S.; Javot, H.; Marin, E.; Nakanishi, T.M.; Thibaud, M.C. Phosphate import in plants: Focus on the PHT1 transporters. Front. Plant Sci. 2011, 2, 83. [CrossRef]

65. Gu, M.; Chen, A.; Sun, S.; Xu, G. Complex regulation of plant phosphate transporters and the gap between molecular mechanisms and practical application: What is missing? Mol. Plant 2016, 9, 396-416. [CrossRef]

66. Bieleski, R.L.; Ferguson, I.B. Physiology and metabolism of phosphate and its compounds. In Encyclopedia of Plant Physiology; Lauchli, A., Bieleski, R.L., Eds.; Springer: Berlin/Heidelberg, Germany, 1983; Volume 15a, pp. $422-449$.

67. Lambers, H.; Plaxton, W.C. Phosphorus: Back to the roots. Ann. Plant Rev. 2015, 48, 3-22.

68. Taliman, N.A.; Dong, Q.; Echigo, K.; Raboy, V.; Saneoka, H. Effect of phosphorus fertilization on the growth, photosynthesis, nitrogen fixation, mineral accumulation, seed yield, and seed quality of a soybean low-phytate line. Plants 2019, 8, 119. [CrossRef]

69. Malhotra, H.; Sharma, S.; Pandey, R. Phosphorus nutrition: Plant growth in response to deficiency and excess. In Plant Nutrients and Abiotic Stress Tolerance; Springer: Singapore, 2018; pp. 171-190.

70. Tian, J.; Venkatachalam, P.; Liao, H.; Yan, X.; Raghothama, K. Molecular cloning and characterization of phosphorus starvation responsive genes in common bean (Phaseolus vulgaris L.). Planta 2007, 227, 151-165. [CrossRef]

71. Elser, J.J.; Fagan, W.F.; Kerkhoff, A.J.; Swenson, N.G.; Enquist, B.J. Biological stoichiometry of plant production: Metabolism, scaling and ecological response to global change. New Phytol. 2010, 186, 593-608. [CrossRef]

72. Raven, J.A. Protein turnover and plant RNA and phosphorus requirements in relation to nitrogen fixation. Plant Sci. 2012, 188, 25-35. [CrossRef] [PubMed]

73. Tran, H.T.; Hurley, B.A.; Plaxton, W.C. Feeding hungry plants: The role of purple acid phosphatases in phosphate nutrition. Plant Sci. 2010, 179, 14-27. [CrossRef]

74. Araujo, A.P.; Plassard, C.; Drevon, J.J. Phosphatase and phytase activities in nodules of common bean genotypes at different levels of phosphorus supply. Plant Soil 2008, 312, 129. [CrossRef]

75. Wasaki, J.; Ando, M.; Ozawa, K.; Omura, M.; Osaki, M.; Ito, H.; Matsui, H. Properties of secretary acid phosphatase from lupin roots under phosphorus-deficient conditions. Soil Sci. Plant Nutr. 1997, 43, 981-986. [CrossRef]

76. Hunter, D.A.; McManus, M.T. Comparison of acid phosphatases in two genotypes of white clover with different responses to applied phosphate. J. Plant Nutr. 1999, 22, 679-692. [CrossRef]

77. George, T.S.; Gregory, P.J.; Hocking, P.; Richardson, A.E. Variation in root-associated phosphatase activities in wheat contributes to the utilization of organic P substrates in vitro, but does not explain differences in the P-nutrition of plants when grown in soils. Environ. Exp. Bot. 2008, 64, 239-249. [CrossRef]

78. Plaxton, W.C. Plant Response to Stress: Biochemical Adaptations to Phosphate Deficiency; Encyclopedia of Plant and Crop Science; Marcel Dekker: New York, NY, USA, 2004; pp. 976-980.

79. Lockhart, H.B.; Hurt, H.D. Nutrition of Oats; American Association of Cereal Chemists: St. Paul, MN, USA, 1986; pp. $297-308$.

80. White, P.J.; Veneklaas, E.J. Nature and nurture: The importance of seed phosphorus content. Plant Soil 2012, 357, 1-8. [CrossRef]

81. Chen, R.; Song, S.; Li, X.; Liu, H.; Huang, D. Phosphorus deficiency restricts plant growth but induces pigment formation in the flower stalk of Chinese kale. Hortic. Environ. Biotechnol. 2013, 54, 243-248. [CrossRef] 
82. Gupta, K.; Barat, G.K.; Wagle, D.S.; Chawla, H.K.L. Nutrient contents and antinutritional factors in conventional and nonconventional leafy vegetables. Food Chem. 1989, 31, 105-116. [CrossRef]

83. Kennedy, G.; Nantel, G. Basic Guidelines for Validation of a Simple Dietary Diversity Score as an Indicator of Dietary Nutrient Adequacy for Non-Breastfeeding Children 2-6 Years; FAO: Rome, Italy, 2006. 